\title{
Role of fatty acid composites in the toxicity of titanium dioxide nanoparticles used in cosmetic products
}

\author{
JuOae Chang ${ }^{1, *}$, Chang-Woo Lee ${ }^{2, *}$, Helal Hussain Alsulimani ${ }^{1}$, Jee Eun Choi ${ }^{1}$, \\ Joo-Kyung Lee ${ }^{3}$, AhYoung Kim³ , Bae Ho Park ${ }^{3}$, Jonghan Kim ${ }^{1}$ and HeaYeon Lee ${ }^{1,4}$ \\ ${ }^{1}$ Department of Pharmaceutical Sciences, Northeastern University, Boston, MA, USA \\ ${ }^{2} R \& D$ Center, Boditech Med Inc., Chuncheon, South Korea \\ ${ }^{3}$ Division of Quantum Phases and Devices, Department of Physics, Konkuk University, Seoul, South Korea \\ ${ }^{4}$ Department of Nano-integrated Cogno-Mechatronics Engineering, Pusan National University, Pusan, South Korea
}

(Received January 22, 2016; Accepted May 24, 2016)

\begin{abstract}
It has been recognized that the use of nanoparticles (NPs) in the cosmetic industry results in products with better efficacy and functionality. However, recent advances in molecular toxicology have revealed that NP exposure can promote cytotoxicity and oxidative damage, which has raised health concerns in the use of NPs in personal care products. Nevertheless, the mechanistic basis for the toxicity and safety of cosmetic NPs is poorly understood. The goal of the study was to determine the cytotoxicity and intracellular distribution of titanium dioxide $\left(\mathrm{TiO}_{2}\right)$ NPs containing fatty acid composites (palmitoleic acid, palmitic acid, stearic acid and oleic acid) commonly used in cosmetic products. Two types of cells, human fibroblast skin cells and adenocarcinoma lung cells, were exposed to either bare $\mathrm{TiO}_{2} \mathrm{NPs}$ or $\mathrm{TiO}_{2} \mathrm{NPs}$ mixed with fatty acids for up to $48 \mathrm{hr}$. NMR analysis confirmed that the fatty acid composites remained in the NPs after wash. The cytotoxicity of $\mathrm{TiO}_{2} \mathrm{NPs}$ was determined by cell viability measurement using quantitative confocal microscopy, and the localization of two different forms of $\mathrm{TiO}_{2} \mathrm{NPs}$ were assessed using electron spectroscopic imaging with transmission electron microscopy. $\mathrm{TiO}_{2} \mathrm{NPs}_{\mathrm{s}}$ containing fatty acids posed significantly reduced cytotoxicity ( $80-88 \%$ decreases) than bare NPs in both cell types. Furthermore, there was less intracellular penetration of the NPs containing fatty acid composites compared with bare NPs. These results provide important insights into the role of fatty acids in protecting the cells from possible toxicity caused by NPs used in the production of cosmetic products.
\end{abstract}

Key words: Cosmetic, Cytotoxicity, Intracellular distribution, Nanosafety, Sunscreens

\section{INTRODUCTION}

Recently, nanomaterials have been extensively applied to cosmetic products due to several advantages. For example, titanium dioxide $\left(\mathrm{TiO}_{2}\right)$ nanoparticles (NPs) have been used as UV-blocking filters for their enhanced protective effect against UV-induced damages and their ability to improve texture and spreadability compared with other conventional metal oxide particles (Singh and Nanda, 2014). Moreover, sunscreens with micronized $\mathrm{TiO}_{2}$ particles reduce risks of sunburn caused by UVB light, possibly through the induction of immune modulators (e.g. interleukin-10) by keratinocytes (van der Molen et al., 1998). In addition to these benefits, less regulato- ry oversight exists in the use of NPs in cosmetic products compared with other medical therapies, and the products can be sold to the consumers without prescription. Such freedom, convenience and benefits have made the use of NPs in cosmetics popular in the market. In 2005, the production of $\mathrm{TiO}_{2}$ NPs was about 2,000 tons, which is worth $\$ 70$ million, and among these, 1,300 tons were used to make personal care products, such as sunscreens and cosmetics (Weir et al., 2012).

In the plethora of personal care products that contain NPs, a large body of evidence has indicated that commonly used NPs, such as $\mathrm{TiO}_{2}$ or zinc oxide, do not penetrate through the skin but remain on the cuticular surface of the skin, suggesting that they do

\footnotetext{
Correspondence: Jonghan Kim (E-mail: j.kim@neu.edu)

HeaYeon Lee (E-mail: he.lee@neu.edu)

*These authors equally contributed to this work.
} 
not pose significant health risks (Sadrieh et al., 2010; Monteiro-Riviere et al., 2011; Filipe et al., 2009). However, concerns remain about potential oxidative injury and DNA damage to the cells caused by direct exposure to NPs (Long et al., 2007; Park et al., 2008; Liu et al., 2010). In addition to these two opposing views on using NPs in the production of personal care products, it has been known that various factors, such as composition and surface modification of NPs, can alter the toxicity of NPs (Kang et al., 2015). Hence, it is important to understand if the components included in cosmetic products could influence the transport of NPs and consequently modify their toxic effects.

Abd Gani et al. (2014) demonstrated that $\mathrm{TiO}_{2}$ particles coated with engkabang fat ester, which contains fatty acids commonly used in cosmetic products, enhanced UVA and UVB absorption. Although this study provides a mechanistic basis for the role of fatty acids in the beneficial effects of $\mathrm{TiO}_{2}$ particles, the safety and toxicity of these composite particles have not been evaluated in cells or living systems. Also, the $\mathrm{TiO}_{2}$ particles were not nanosized and thereby failed to represent the most commonly used forms of $\mathrm{TiO}_{2}$ particles found in personal care products. In addition, whether or not $\mathrm{TiO}_{2} \mathrm{NPs}$ in sunscreens could modify intracellular particle dissolution and consequently alter cytotoxicity is poorly understood. To examine the toxicity of $\mathrm{TiO}_{2}$ NPs in cosmetics, we mixed the $\mathrm{TiO}_{2}$ NPs with common fatty acids used as composites of cosmetics and compared their effects on cell viability with those of the bare $\mathrm{TiO}_{2}$ NPs (B-NPs). We used four fatty acids (i.e. palmitoleic acid, oleic acid, palmitic acid and stearic acid) as fatty acid composites because they are commonly mixed in cosmetic products (Zielińska and Nowak, 2014; Andersen, 1987). Two types of cell culture systems, human fibroblast skin cells and human adenocarcinoma lung cells, were used to mimic most common exposure routes of the NPs used in cosmetics. Skin cells represent a primary site of cosmetic application in which exposure occurs through topical application of cosmetics. Lung cells portray exposure through inhalation of NPs that could occur through spray or powder formulations of the cosmetics (Nazarenko et al., 2012), as well as occupational settings in the cosmetic-producing plants (CDC, 2011). We demonstrate that $\mathrm{TiO}_{2}$ NPs in the presence of fatty acids exhibit decreased intracellular uptake of NPs and further protect cells from cytotoxicity caused by NP exposure.

\section{MATERIALS AND METHODS}

\section{Cell culture}

Human fibroblast skin (CCD-986SK) cells and adenocarcinoma lung (SK-LU-1) cells were provided by the Korean Cell Line Bank (Seoul, South Korea). The culture of cells was maintained in a phenol-red-free culture medium, Dulbecco's modified essential medium (Gibco, Grand Island, NY, USA), supplemented with 5\% (v/v) fetal bovine serum (Gibco) and 1\% (v/v) antibiotics (2 mM L-glutamine, $100 \mathrm{U} / \mathrm{mL}$ penicillin and $0.1 \mathrm{mg} / \mathrm{mL}$ streptomycin; Gibco). Cultured cells were kept at $37^{\circ} \mathrm{C}$ in a humidified $5 \% \mathrm{CO}_{2}$ incubator. Once the cells reached confluence, the culture medium was removed from the culture dish, and the cells were rinsed twice with sterile Dulbecco's phosphate-buffered saline (DPBS; Gibco). The confluent cell layers were enzymatically removed using trypsin/EDTA (Gibco) and resuspended in the culture medium.

\section{Preparation of $\mathrm{TiO}_{2} \mathrm{NPs}$}

A stock solution of $\mathrm{TiO}_{2}(0.5 \mathrm{M})$ was prepared by mixing titanium isopropoxide (TTIP) and triethanolamine (TEOA) with a molar ratio of TTIP:TEOA $=1: 2$, followed by the addition of distilled water. The stock solution $\left(\mathrm{pH} \sim 9.5\right.$ ) was then mixed with $\mathrm{HClO}_{4}$ or $\mathrm{NaOH}$ solutions to adjust the $\mathrm{pH}$ of the solution to 10.5 . Ethylenediamine $(0.4 \mathrm{M})$ was further added as a shape controller. The solution was placed in an autoclave, aged at $100^{\circ} \mathrm{C}$ for $24 \mathrm{hr}$ (first aging) and further aged at $140^{\circ} \mathrm{C}$ for $72 \mathrm{hr}$ (second aging). The two-step aging process is essential to obtain uniform $\mathrm{TiO}_{2}$ NPs because a hydrolyzed gel network forms during the first aging step, and the nucleation and growth of $\mathrm{TiO}_{2}$ seeds occur during the second aging step. The gel matrix plays two decisive roles in the second aging to produce uniform particles: (i) as a reservoir of metal ions to lower the supersaturation and prevent extensive nucleation and (ii) as an anticoagulant that fixes the growing particles in the matrix. An opaque solution was obtained after the second aging process via transformation from the gel, and the resultant NPs dispersed in the solution were washed with $\mathrm{NaOH}$ (six times), $\mathrm{HNO}_{3}$ (two times) and distilled water (four times) to remove residual organic compounds from their surfaces.

\section{Preparation of nanoparticles coated with fatty acids}

The $\mathrm{TiO}_{2}$ B-NPs were initially placed into distilled water (particle concentration $=74.1 \mu \mathrm{g} / \mathrm{mL}$ ) and dispersed. The initial suspension was dried and resuspended in distilled water to generate a B-NP stock suspension 
Role of fatty acid composites in the toxicity of $\mathrm{TiO}_{2}$ nanoparticles

at $3,000 \mu \mathrm{g} / \mathrm{mL}$. Subsequently, the B-NP stock was diluted with distilled water or with fatty acids composites to produce B-NPs or CM-NPs, respectively. For CM-NPs, B-NPs were first mixed with 1\% sepinov EMT 10 and stirred for $5 \mathrm{~min}$, followed by an addition of fatty acids composites consisting of 5\% jojoba oil (palmitoleic acid and palmitic acid), 14.9\% emu oil (stearic acid and oleic acid), and 5\% glycerin. After 15 min of stirring, a cream was formed. The final product was obtained after holding the cream at $4^{\circ} \mathrm{C}$ for $24 \mathrm{hr}$. This dilution step was repeated to produce lower concentrations of $\mathrm{TiO}_{2} \mathrm{CM}-\mathrm{NPs}$.

\section{${ }^{1} \mathrm{H}-$ Nuclear magnetic resonance ( $\left.{ }^{1} \mathrm{H}-\mathrm{NMR}\right)$}

The presence of fatty acids on CM-NPs was determined by ${ }^{1} \mathrm{H}-\mathrm{NMR}$. The analysis was conducted using Bruker AVANCE 300 NMR spectrometer (Bruker, Billerica, MA, USA) using a well-cleaned $5 \mathrm{~mm}$ NMR tube. Both CM-NPs and B-NPs were suspended in ethanol and centrifuged at 13,000 rpm for $10 \mathrm{~min}$ to remove the supernatant. After repeated washes for five times, NPs were fully dried in the oven at $70^{\circ} \mathrm{C}$. Dibromomethane was added as internal standard, deuterated chloroform $\left(\mathrm{CDCl}_{3}\right)$ as lock solvent and tetramethylsilane (TMS) as peak calibration reference.

\section{Cell exposure to NPs}

Both human fibroblast skin and adenocarcinoma lung cells were seeded at a density of $2.5 \times 10^{4}$ cells per well in 24-well plates. After one day (attachment phase), the cells were treated with B-NPs or CM-NPs at $\mathrm{TiO}_{2}$ concentrations of $0,1.95,3.9,7.81,16.25,31.25,62.5,125$, 250,500 , and $1,000 \mu \mathrm{g} / \mathrm{mL}$ and incubated for 24 or $48 \mathrm{hr}$ at $37^{\circ} \mathrm{C}$.

\section{Cytotoxicity assessment}

After the exposure of cells to $\mathrm{TiO}_{2}$ NPs, the supernatant was removed, and the cells were washed twice with DPBS. They were then subject to staining by propidium iodide (PI, cell-nonpermeable red fluorescent dye) and Live-Dye (cell-permeable green fluorescent dye) using a Live-Dead Cell Staining Kit (K501-100; BioVision Research Products, Milpitas, CA, USA). After staining, red and green fluorescence was observed under UV illumination using a confocal microscope (model C1; Nikon, Minato, Tokyo, Japan). Cells that appeared red under UV illumination were considered dead because PI is preferentially absorbed by dead cells. Green fluorescent cells were recognized as living because Live-Dye is preferentially absorbed by live cells. After counting the dead and living cells, the cytotoxicity at each $\mathrm{TiO}_{2}$ concentration was assessed by the following calculation: dead cells / (living cells + dead cells $) \times 100$. The cytotoxicity results from different concentrations of NPs were further analysed using the hyperbolic effect model function (SigmaPlot 12.3; Systat, Chicago, IL, USA) to quantitatively characterize the maximal cell death effect $\left(\mathrm{E}_{\max }\right)$ and the concentration of $\mathrm{TiO}_{2}$ at which $50 \%$ of cytotoxicity was achieved $\left(\mathrm{EC}_{50}\right)$.

\section{Transmission electron microscopy}

To characterize intracellular localization of $\mathrm{TiO}_{2} \mathrm{NPs}$, cells exposed to the NPs were sampled for electron spectroscopic imaging (ESI) with transmission electron microscopy (TEM) as follows. The fresh samples were rinsed three times with DPBS and fixed for $30 \mathrm{~min}$ in modified Karnovsky fixative using glutaraldehyde $(2.5 \% \mathrm{v} / \mathrm{v})$ and paraformaldehyde $(2 \% \mathrm{w} / \mathrm{v})$ in a cacodylate buffer (0.1 M, pH 7.2-7.4) with calcium chloride (2.5 mM). The samples were then rinsed three times with a cacodylate wash buffer for $5 \mathrm{~min}$. Next, they were fixed in osmic acid (2\%) for $15 \mathrm{~min}$ and stained in a saturated aqueous solution of uranyl acetate for $15 \mathrm{~min}$. The dehydration process was performed in a graded series of $30 \%, 50 \%$, $70 \%, 95 \%$, and twice in $100 \%$ ethanol, for $15 \mathrm{~min}$ each. Then the samples were infiltrated with a 50:50 mixture of $100 \%$ ethanol and Spurr's reagent. After the mixture was discarded during $1 \mathrm{hr}, 100 \%$ Spurr's reagent was added to infiltrate the cells for another $1 \mathrm{hr}$. The samples were kept in a vacuum oven at $60^{\circ} \mathrm{C}$ overnight after the Spurr's reagent was changed. Finally, the samples were cut into light-gold-colored ultrathin sections with a microtome and stained on the grid with uranyl acetate and lead oxide ( 5 min each). After being washed with distilled water, the TEM cell samples were dried and then imaged under a Carl Zeiss (model LIBRA® 200; Carl, Zeiss, Oberkochen, Germany) energy-filtered TEM. The images were analyzed to characterize the penetration, distribution and specific locations of the $\mathrm{TiO}_{2}$ NPs by ESI.

\section{RESULTS}

\section{Fatty acids mixed with $\mathrm{TiO}_{2}$ NPs remain on the NP surface}

The CM-NPs were produced by mixing the $\mathrm{TiO}_{2}$ B-NPs with fatty acids (Fig. 1a). NMR analysis demonstrated that the peaks of fatty acids were still observed in the CM-NPs after wash (Fig. 1b), indicating that most fatty acids remain on the surface of $\mathrm{TiO}_{2}$ NPs. These results suggest a potential surface modification of NPs by fatty acid composites. 


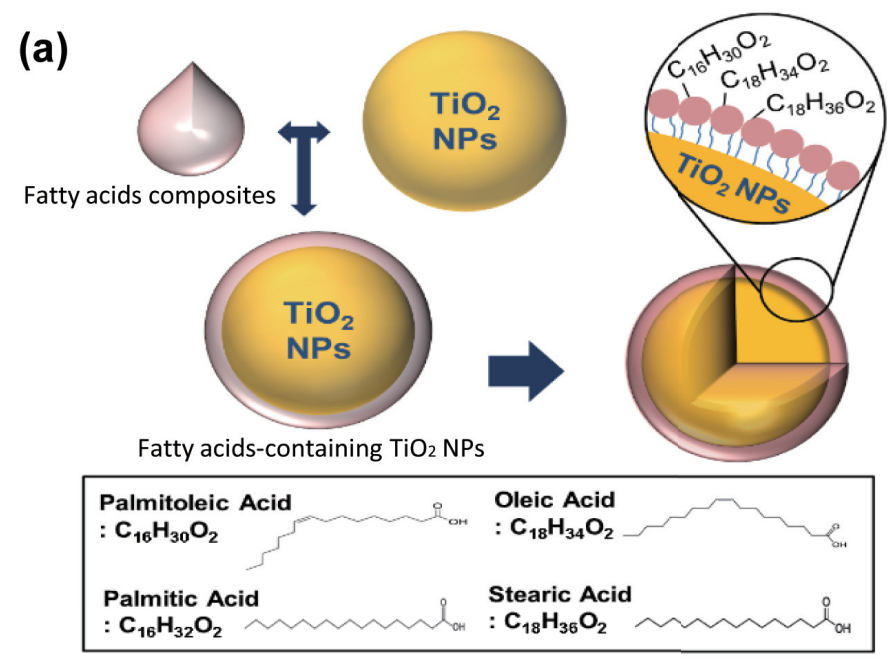

(b)

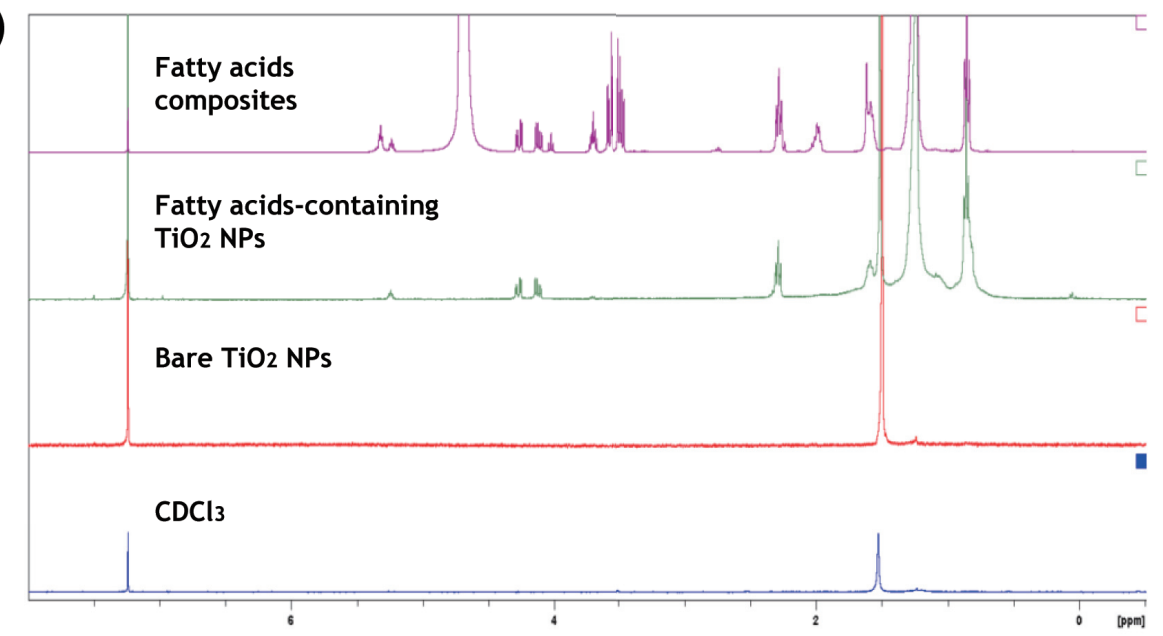

Fig. 1. Physicochemical properties of CM-NPs. (a) CM-NPs were generated by mixing $\mathrm{TiO}_{2} \mathrm{NPs}$ with palmitoleic acid, oleic acid, palmitic acid, and stearic acid. (b) Cosmetics mixture of fatty acids, washed CM-NPs, and washed B-NPs were analysed by ${ }^{1} \mathrm{H}-\mathrm{Nuclear}$ Magnetic Resonance ( $\left.{ }^{1} \mathrm{H}-\mathrm{NMR}\right)$ using $\mathrm{CDCl}_{3}$ as a lock solvent.

\section{Fatty acid composites reduce NP-induced cytotoxicity in fibroblast skin cells}

The fibroblast skin cells were exposed to B-NPs and CM-NPs at $\mathrm{TiO}_{2}$ concentrations of $0-1,000 \mu \mathrm{g} / \mathrm{mL}$ for $24 \mathrm{hr}$ or $48 \mathrm{hr}$ and dead/living cell counts were analysed by confocal microscopy (Fig. 2). There were no dead cells observed in the control cells without exposure to NPs, whereas exposure to $\mathrm{TiO}_{2} \mathrm{NPs}$ at $1,000 \mu \mathrm{g} / \mathrm{mL}$ resulted in cell death (Fig. 2a). Of importance, more dead cells were found in cells exposed to $\mathrm{TiO}_{2}$ B-NPs $(85 \%$ dead cells) than those exposed to $\mathrm{TiO}_{2}$ CM-NPs (54\%) (Fig. 2a). These results indicate that fatty acid composites in NPs could protect skin cells from cytotoxicity induced by $\mathrm{TiO}_{2}$ NP exposure.
We also characterized the dose-toxicity relationship of $\mathrm{TiO}_{2}$ NPs by cell counting (Fig. 2b). The cytotoxicity of skin fibroblast cells exposed to B-NPs for 24 and $48 \mathrm{hr}$ increased rapidly up to the NP concentration of $250 \mu \mathrm{g} / \mathrm{mL}$, above which the rate slowed down. However, cells exposed to $\mathrm{TiO}_{2} \mathrm{CM}-\mathrm{NPs}$ for $24 \mathrm{hr}$ did not demonstrate appreciable changes in cytotoxicity at NP concentrations below $250 \mu \mathrm{g} / \mathrm{mL}$. At low NP concentrations (below $62.5 \mu \mathrm{g} / \mathrm{mL}$; Fig. $2 \mathrm{~b}$ ), $<10 \%$ of cells were dead when exposed to $\mathrm{TiO}_{2}$ CM-NPs, whereas B-NPs killed $>30 \%$ of cells within $24 \mathrm{hr}$. As expected, the cytotoxicity of NPs was greater in 48-hr exposure compared with 24-hr exposure. Interestingly, the protective effect of CMNPs on cytotoxicity still remained at low concentrations, 


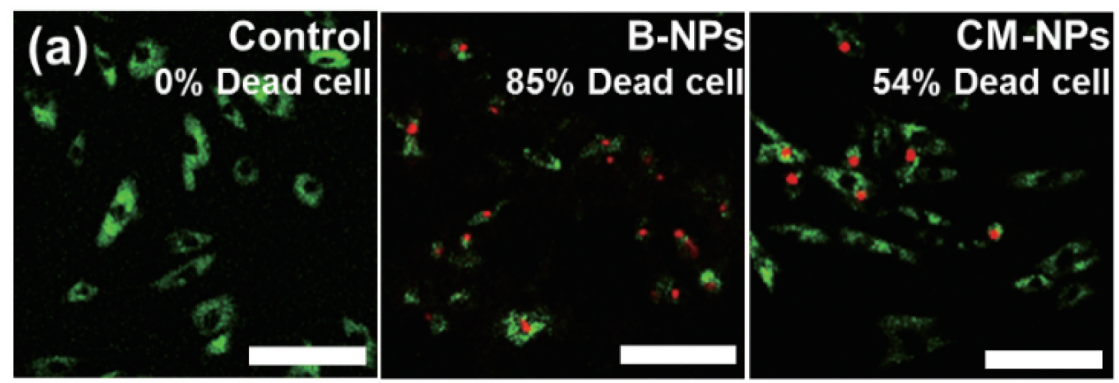

(b)

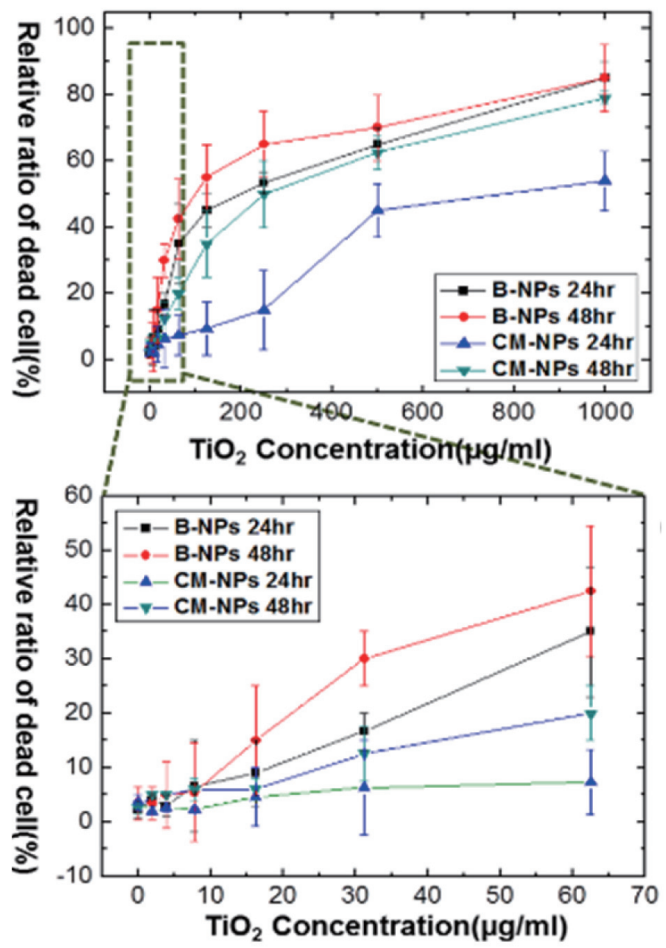

Fig. 2. Effect of fatty acid composites on cytotoxicity of $\mathrm{TiO}_{2} \mathrm{NPs}$ in fibroblast skin cells. (a) Cell viability was visualized by confocal microscope images after exposing fibroblast skin cells to $\mathrm{TiO}_{2} \mathrm{~B}-\mathrm{NPs}$ and $\mathrm{CM}-\mathrm{NPs}$ for $24 \mathrm{hr}$ to a $\mathrm{TiO}_{2}$ concentration of $1,000 \mu \mathrm{g} / \mathrm{mL}$. Living and dead cells are visualized by green and red fluorescent proteins, respectively. Scale bar $=200 \mu \mathrm{m}$. (b) Cytotoxicity after exposure to $\mathrm{TiO}_{2} \mathrm{NPs}$ was plotted over different $\mathrm{TiO}_{2}$ concentrations $(0-1,000 \mu \mathrm{g} / \mathrm{mL})$. The enlarged graph indicates the cytotoxicity results after exposure to $0-70 \mu \mathrm{g} / \mathrm{mL}$ of $\mathrm{TiO}_{2}$ concentrations.

but this effect was less prominent at high concentrations and longer exposure. Together, these results indicate that $\mathrm{TiO}_{2} \mathrm{CM}-\mathrm{NPs}$ induce less cell death compared with the B-NPs, while this effect is less significant after prolonged exposure to NPs.

Table 1 provides a summary of the cytotoxicity parameters of $\mathrm{TiO}_{2}$ NPs at concentrations of $0-1,000 \mu \mathrm{g} /$ $\mathrm{mL}$ in the skin cell culture. The $\mathrm{EC}_{50}$ value $\left(\right.$ as $\mathrm{TiO}_{2}$ ) of CM-NPs was almost doubled $(219 \mu \mathrm{g} / \mathrm{mL})$ compared with that of B-NPs $(66 \mu \mathrm{g} / \mathrm{mL})$ after $48-\mathrm{hr}$ exposure, indicating that the CM-NP toxicity is significantly decreased. When the cells were exposed to NPs for $24 \mathrm{hr}$, the difference in the $\mathrm{EC}_{50}$ values were even more dramatic; CM-NPs were 8.5 times less toxic than B-NPs (i.e. $88 \%$ decrease in cytotoxicity). These data indicate that fatty acid composites are important in reducing $\mathrm{TiO}_{2} \mathrm{NP}$-induced toxicity in human fibroblast cells. 
Table 1. Cytotoxicity parameters of human fibroblast skin cells exposed to $\mathrm{TiO}_{2}$ NPs.

\begin{tabular}{lcc}
\hline $\mathrm{TiO}_{2} \mathrm{NPs}$ & $\mathrm{E}_{\max } \%$ & $\mathrm{EC}_{50,}, \mu \mathrm{g} / \mathrm{mL}$ \\
\hline B-NPs 24 hr & $88.6 \pm 5.4(6.0)$ & $125.1 \pm 23.6(18.8)$ \\
B-NPs 48 hr & $85.4 \pm 2.9(3.4)$ & $66.0 \pm 8.0(12.1)$ \\
CM-NPs 24 hr & $116 \pm 40.1(34.7)$ & $1062 \pm 602(56.6)$ \\
CM-NPs 48 hr & $94.0 \pm 4.0(4.3)$ & $219 \pm 25.1(11.5)$ \\
\hline
\end{tabular}

Data shown as means \pm standard errors (\% coefficient of variation). $\mathrm{E}_{\max }$, the maximum capacity of cytotoxicity; $\mathrm{EC}_{50}$, the $\mathrm{TiO}_{2}$ concentration at which a half of cells are dead (potency of cytotoxicity).

\section{Fatty acids on $\mathrm{TiO}_{2}$ NP surface protect adenocarcinoma lung cells from cell death}

In addition to fibroblast cells, human adenocarcinoma lung cells (SK-LU-1) were exposed to various concentrations of NPs (Fig. 3). Exposure to B-NPs at a $\mathrm{TiO}_{2}$ concentration of $1,000 \mu \mathrm{g} / \mathrm{mL}$ for $24 \mathrm{hr}$ resulted in almost complete cell death ( $97 \%$ dead cells), as determined by confocal microscopy. In contrast, CM-NPs significantly reduced cell death $(41 \%)$, similar to results from skin fibroblast cultures (Fig. 3a). While dead cell ratios after 24-hr and 48-hr exposure to B-NPs increased at the concentration of $16.25 \mu \mathrm{g} / \mathrm{mL}$ and reached a plateau value of
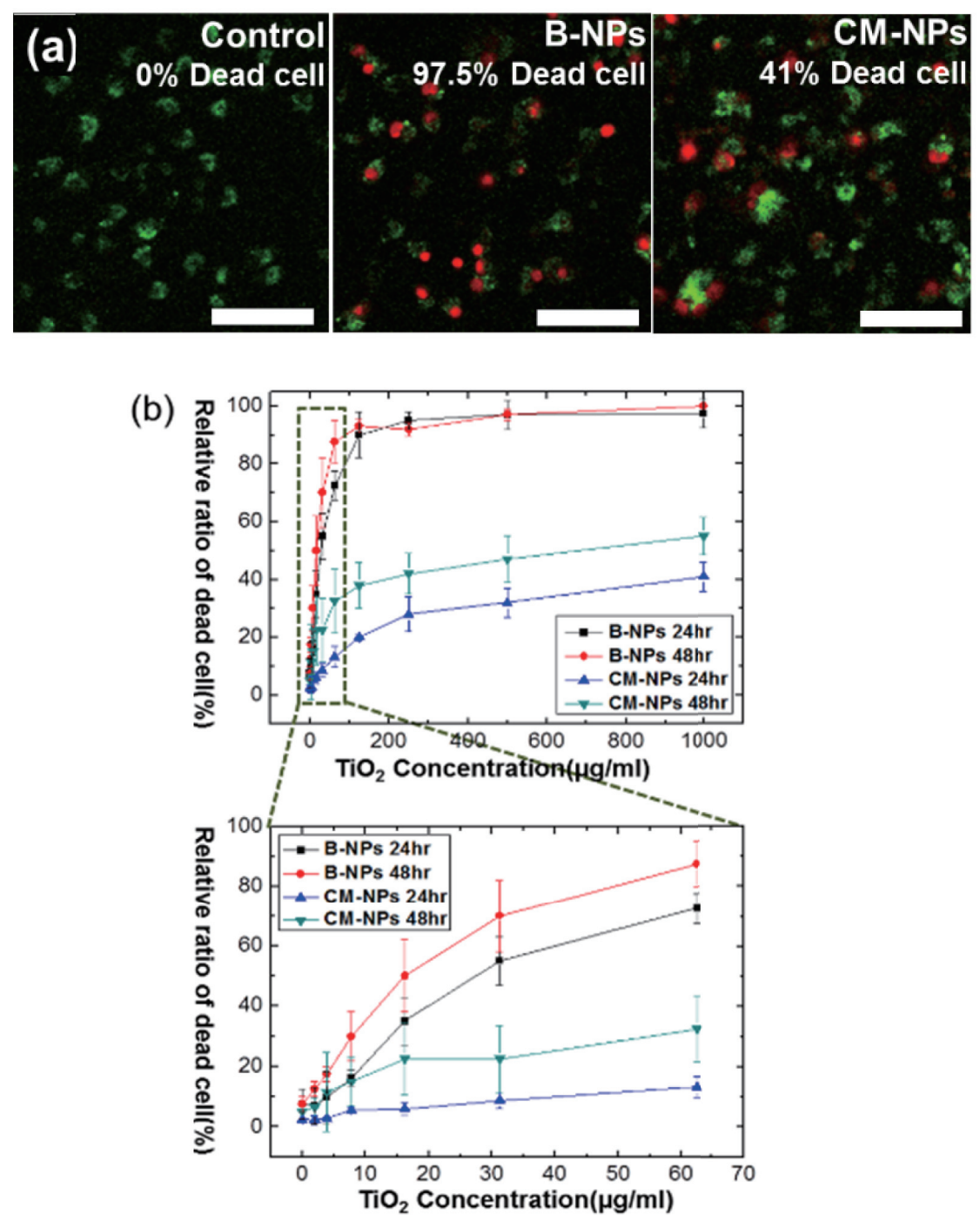

Fig. 3. Effect of fatty acid composites on cytotoxicity of $\mathrm{TiO}_{2} \mathrm{NPs}$ in adenocarcinoma lung cells. (a) Cell viability was visualized by confocal microscope images after exposing adenocarcinoma lung cells to $\mathrm{TiO}_{2} \mathrm{~B}-\mathrm{NPs}$ and CM-NPs for $24 \mathrm{hr}$ to a $\mathrm{TiO}_{2}$ concentration of $1,000 \mu \mathrm{g} / \mathrm{mL}$. Scale bars $=200 \mu \mathrm{m}$. (b) Cytotoxicity after exposure to $\mathrm{TiO}_{2} \mathrm{NPs}$ was plotted over different $\mathrm{TiO}_{2}$ concentrations $(0-1,000 \mu \mathrm{g} / \mathrm{mL})$. The enlarged graph indicates the cytotoxicity results after exposure to $0-70 \mu \mathrm{g} / \mathrm{mL}$ of $\mathrm{TiO}_{2}$ concentrations. 
Role of fatty acid composites in the toxicity of $\mathrm{TiO}_{2}$ nanoparticles

$90 \%$ (i.e. almost all cells were dead cells) at concentrations above $125 \mu \mathrm{g} / \mathrm{mL}$, the cytotoxicity by CM-NPs after 24-hr and 48-hr exposure increased slowly to $20 \%$ and $38 \%$, respectively (Fig. 3 b). In contrast to skin fibroblast results, the cytotoxicity of CM-NPs after 48-hr exposure was significantly reduced compared with B-NPs, suggesting that the protective effect of fatty acid composites is greater in lung cells than in skin cells.

Table 2 shows quantitative measures of the cytotoxicity of B-NPs and CM-NPs in lung cells. The cytotoxicity in lung cells was reduced in CM-NPs compared with B-NPs. Interestingly, the $\mathrm{E}_{\max }$ values were also decreased in cells exposed to CM-NPs. These results indicate that mixing NPs with fatty acids reduces the potency of NPinduced cytotoxicity $(80 \%$ decrease in cytotoxicity or 4.9-fold increase in $\mathrm{EC}_{50}$ after 24-hr exposure; 1.6-fold increase in $\mathrm{EC}_{50}$ after 48-hr exposure).

\section{Cosmetic composites attenuate intracellular uptake of $\mathrm{TiO}_{2} \mathrm{NPs}$}

TEM images were analyzed to identify $\mathrm{TiO}_{2}$ B-NPs and CM-NPs within an individual fibroblast skin or adenocarcinoma lung cell. In addition, element analysis with ESI was necessary to observe precise intracellular localization of NPs. Both B-NPs and CM-NPs with a size of 20-30 nm $\mathrm{TiO}_{2}$ (Fig. 4, a and b, respectively) entered the fibroblast skin cells after 24-hr exposure. However, the
Table 2. Cytotoxicity parameters of human adenocarcinoma lung cells exposed to $\mathrm{TiO}_{2}$ NPs.

\begin{tabular}{lcc}
\hline $\mathrm{TiO}_{2} \mathrm{NPs}$ & $\mathrm{E}_{\max } \%$ & $\mathrm{EC}_{50,}, \mu \mathrm{g} / \mathrm{mL}$ \\
\hline B-NPs 24 hr & $104 \pm 2.1(2.0)$ & $28.7 \pm 2.5(8.6)$ \\
B-NPs 48 hr & $102 \pm 2.0(1.9)$ & $15.3 \pm 1.4(9.1)$ \\
CM-NPs 24 hr & $44.2 \pm 2.7(6.1)$ & $141 \pm 25.8(18.3)$ \\
CM-NPs 48 hr & $49.4 \pm 2.8(5.8)$ & $24.1 \pm 6.0(25.0)$ \\
\hline
\end{tabular}

Data shown as means \pm standard errors (\% coefficient of variation). $\mathrm{E}_{\max }$, the maximum capacity of cytotoxicity; $\mathrm{EC}_{50}$, the $\mathrm{TiO}_{2}$ concentration at which a half of cells are dead (potency of cytotoxicity).

pattern of intracellular distribution of the two types of NPs was different: B-NPs (Fig. 4a') entered the cells in a greater extent than the CM-NPs (Fig. 4b'). Similar results were obtained in human adenocarcinoma lung cells exposed to B-NPs and CM-NPs for $24 \mathrm{hr}$ (Fig. 4, c and d). In the B-NP-exposed lung cells, many nanomaterials were homogeneously distributed in a large area inside a cellular vesicle (Fig. 4c'). In contrast, CM-NPs appeared isolated as slightly dense groups in small areas of the cell (Fig. 4d'). Combined, these results indicate that mixing of $\mathrm{TiO}_{2}$ NPs with fatty acid composites reduces intracellular uptake of toxic $\mathrm{TiO}_{2}$ NPs in both types of cells.

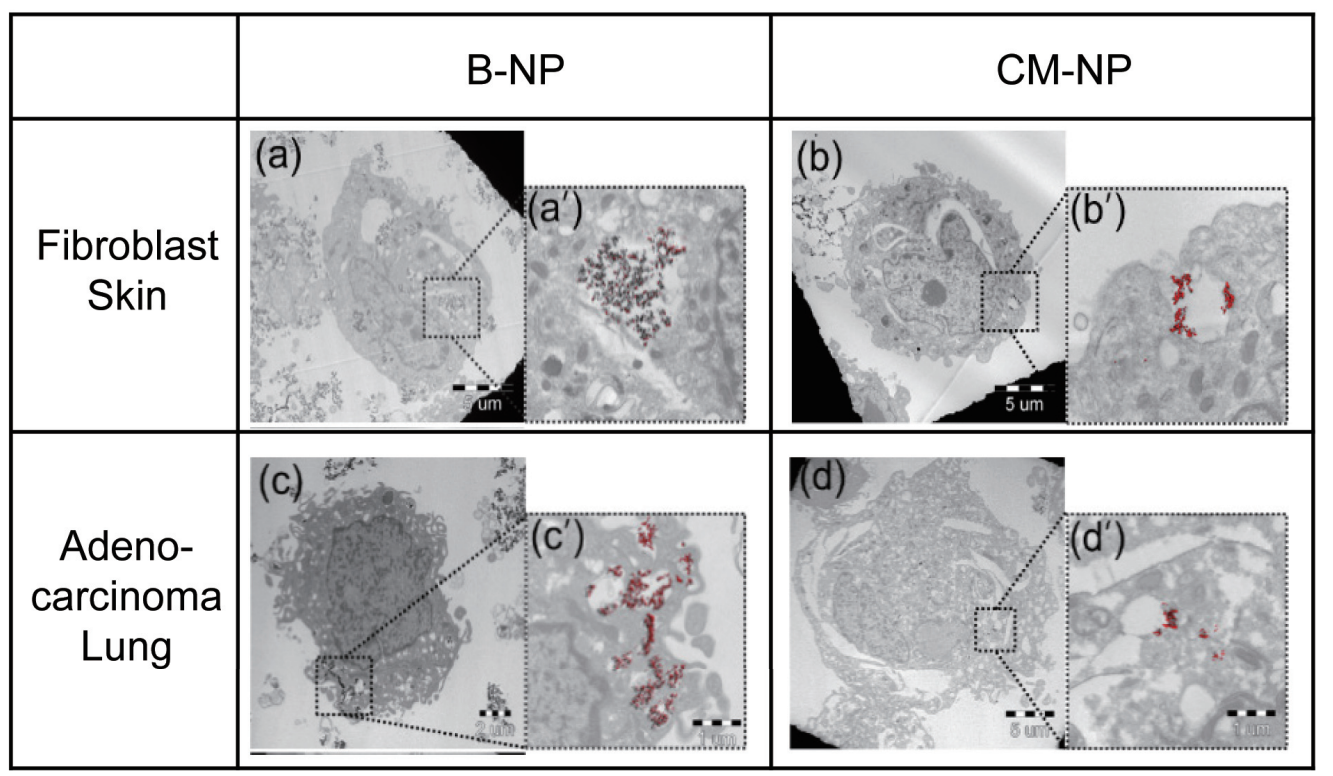

Fig. 4. Intracellular localization of $\mathrm{TiO}_{2} \mathrm{NPs}$ in fibroblast skin cells and adenocarcinoma lung cells. ESI-TEM analysis was conducted using fibroblast skin cells $\left[(\mathrm{a})\right.$ and (b)] and adenocarcinoma lung cells $\left[(\mathrm{c})\right.$ and (d)] after exposure to $\mathrm{TiO}_{2} \mathrm{~B}-\mathrm{NPs}[(\mathrm{a})$ and (c)] and CM-NPs [(b) and (d)] for $24 \mathrm{hr}$. (a')-(d') correspond to enlarged images of square boxes in (a)-(d). Scale bars = $5 \mu \mathrm{m}(\mathrm{a}, \mathrm{b}$ and $\mathrm{d}), 2 \mu \mathrm{m}(\mathrm{c})$ and $1 \mu \mathrm{m}\left(\mathrm{a}^{\prime}-\mathrm{d}^{\prime}\right)$. 


\section{J. Chang et al.}

\section{DISCUSSION}

An increasing body of evidence has indicated that a direct exposure of cells to the NPs can increase the production of reactive oxygen species (ROS) and cause oxidative injury and DNA damage (Park et al., 2008; Long et al., 2007; Liu et al., 2010; Shukla et al., 2011; Heng et al., 2010; Sharma et al., 2009). Although the multilayer skin system prevents NPs from entering into the deep skin layer (Xie et al., 2015; Schilling et al., 2010; Newman et al., 2009; Sadrieh et al., 2010; MonteiroRiviere et al., 2011; Filipe et al., 2009), surface modification of NPs that are commonly used in cosmetics, such as $\mathrm{TiO}_{2}$ or zinc oxide, could alter the transport of NPs and thereby alter the cytotoxicity of NPs. Abd Gani et al. (2014) showed that coating $\mathrm{TiO}_{2}$ particles with fatty acids commonly used in cosmetics can increase UV absorption, but have not demonstrated the efficacy of "nanosized" particles. Leung et al. (2012) observed that the antibacterial activity is enhanced as a result of surface modification of zinc oxide NPs. However, neither study examined the effect of surface modification of NPs in cell toxicity. In particular, Serpone et al. (2001) suggested surface modification as a method to reduce NP-induced DNA damage, but the idea has not been tested in vitro or in vivo. We here show that $\mathrm{TiO}_{2}$ NPs in themselves possess considerable cytotoxicity when exposed directly to skin and lung cells, but fatty acid composites typically found in cosmetic products significantly reduce NP-associated cytotoxicity. To our knowledge, this is the first study to directly examine a protective role of fatty acid components in NPinduced cell toxicity.

Our results demonstrated decreased penetration and increased cell viability of the CM-NPs compared with the B-NPs, suggesting that the changes in NP kinetics likely alter the cytotoxicity of NP exposure. Several physicochemical and physiological factors influence the uptake of NPs (Kang et al., 2015). In particular, surface modification can alter the extent and rate of cell entrance of NPs. For example, positive charges on the NPs increase electrostatic interaction with the negatively-charged membrane, thereby promoting cellular uptake (Salatin et al., 2015). In some instances, surface modification of NPs affects not only intracellular uptake, but also subcellular distribution inside the cell. Nativo et al. (2008) illustrated that gold NPs that are chemically modified with membrane-penetrating peptide sequences are able to escape from lysosomal digestion inside the cell and direct NPs to the nucleus. Importantly, Abd Gani et al. (2014) demonstrated that engkabang oil-coated $\mathrm{TiO}_{2}$ particles increase zeta potential without changing overall negative charge of the particles. Higher zeta potentials suggest increased repelling force among particles, thereby forming fewer agglomerates. Since the agglomerates are more easily taken up by the cell via endocytic transport than individual NPs (Andersson et al., 2011), our results of reduced penetration of the CM-NPs could be explained by decreased degree of agglomeration, likely due to fatty acid-associated surface modification. Future studies should be carried out to understand possible changes in the charge, subcellular distribution, zeta potential and agglomerate formation of $\mathrm{TiO}_{2} \mathrm{NPs}$ coated with fatty acids.

In the current study, we characterized the cytotoxicity and extent of intracellular localization of $\mathrm{TiO}_{2} \mathrm{NPs}$ mixed with fatty acid composites compared with bare $\mathrm{TiO}_{2} \mathrm{NPs}$ as a control source material. Although our results indicate that fatty acids significantly decreased the cytotoxicity of NPs, our study is limited to in vitro findings within $48 \mathrm{hr}$. Our results demonstrate that cells exposed to CM-NPs for $48 \mathrm{hr}$ caused more damage to cells than the 24-hr exposure, indicating that prolonged exposure increases cytotoxicity. Interestingly, in fibroblast skin cells the 48-hr exposure to CM-NPs produced similar results to those from 24-hr exposure to B-NPs. One explanation could be a possible removal of fatty acids from the $\mathrm{TiO}_{2} \mathrm{CM}-\mathrm{NPs}$ with prolonged incubation, which consequently alters intracellular distribution and toxicity of NPs. A characterization of fatty acid contents in the remaining $\mathrm{TiO}_{2} \mathrm{CM}$ NPs after 24- to 48-hr incubation would address this question. In addition, a future study is necessary to explore the long-term effect of fatty acids on $\mathrm{TiO}_{2} \mathrm{NP}$-induced toxicity to represent more realistic subchronic or chronic exposure. Moreover, it is important to verify the protective role of fatty acid composites against adverse effects of $\mathrm{TiO}_{2}$ NPs by other types of toxicity measures, such as the comet assay (Bhabra et al., 2009; Shukla et al., 2013). Also, it remains to be examined whether or not these beneficial effects of surface modification also exist in vivo. These studies will provide an important insight into the establishment of safety and toxicity profiles in the use of NPs in cosmetics that are often used over a long period of time.

Several other approaches will help to better understand the molecular mechanisms of NP-mediated cytotoxicity and further confirm the utility and safety of the use of CM-NPs. Xiong et al. (2013) revealed that $\mathrm{TiO}_{2} \mathrm{NPs}$ enhance the generation of ROS, plasma membrane damage and depolarization of mitochondria by high throughput screening and ELISA. Whether or not CM-NPs cause less DNA damage or oxidative stress should be rigorously tested by specific assays that assess nuclear and mitochondrial damage as well as ROS production. Related to 
Role of fatty acid composites in the toxicity of $\mathrm{TiO}_{2}$ nanoparticles

this idea, it is possible that low doses of NPs with prolonged exposure may not elicit direct, visible cytotoxicity, but could be sufficient to generate ROS. This is an important question since emerging evidence has suggested that elevated ROS levels are closely associated with the process of aging and progressive impairment in cellular function (Genova et al., 2004; Schöneich, 1999; Circu and Aw, 2010; Seifried et al., 2007). Furthermore, the cytotoxicity of soluble metals resulting from intracellular dissolution of metal NPs should be rigorously examined. Numerous studies have demonstrated biochemical alterations and behavioural dysfunction in animals and humans caused by exposure to various metals (Chang et al., 2014; Ye and Kim, 2015a, 2015b; Menon et al., 2016). Measuring the soluble metal concentrations of NP-exposed cells and cell culture media would provide important information about the potential effect of NP dissolution on metal toxicity. Also, these studies can benefit from more relevant cell culture models. For example, Bhabra et al. (2009) utilized a multilayer cell system to replicate cellular barriers in human tissues and demonstrated DNA damage by cobalt-chromium NPs to the deepest cell layer below the barrier even without direct contact, suggesting ATP as a signaling molecule that communicates the DNA damage to the lowest layer of cells. In addition, it is important to identify which of the four fatty acids used in current study provide(s) most significant protective effect from cytotoxicity. Likewise, the effect of cosmetic components other than fatty acids on cell viability remains to be characterized. These efforts will increase our understanding about the toxicity of metal oxide NPs not only in the use of personal care products in everyday lives, but in other medical diagnostic and therapeutic applications.

\section{ACKNOWLEDGMENTS}

This work was supported in part by the Ministry of Science, ICT and Future Planning (MSIP) (No. 2014-052607 for H.Y.L.; No. 2013R1A3A2042120 for J.K.L., A.Y.K., and B.H.P.). The authors are grateful to Dr. Kyuhong Lee (KIT) for help during NMR analysis.

Conflict of interest---- The authors declare that there is no conflict of interest.

\section{REFERENCES}

Abd Gani, S.S., Basri, M., Kassim, A., Raja Abdul Rahman, R.N.Z., Salleh, A.B. and Ismail, Z. (2014): Characterization of encapsulated titanium dioxide using engkabang fat esters for cosmeceutical purposes. Int. J. Pharm. Chem. Biol. Sci., 4, 725-737.

Andersen, F. (1987): Final Report on the Safety Assessment of Oleic
Acid, Lauric Acid, Palmitic Acid, Myristic Acid, and Stearic Acid. J. Am. Coll. Toxicol., 6, 321-401.

Andersson, P.O., Lejon, C., Ekstrand-Hammarström, B., Akfur, C., Ahlinder, L., Bucht, A. and Osterlund, L. (2011): Polymorphand size-dependent uptake and toxicity of $\mathrm{TiO}_{2}$ nanoparticles in living lung epithelial cells. Small, 7, 514-523.

Bhabra, G., Sood, A., Fisher, B., Cartwright, L., Saunders, M., Evans, W.H., Surprenant, A., Lopez-Castejon, G., Mann, S., Davis, S.A., Hails, L.A., Ingham, E., Verkade, P., Lane, J., Heesom, K., Newson, R. and Case, C.P. (2009): Nanoparticles can cause DNA damage across a cellular barrier. Nat. Nanotechnol., $4,876-883$.

CDC (2011): Occupational Exposure to Titanium Dioxide. Current Intelligence Bulletin 63.

Chang, J., Kueon, C. and Kim, J. (2014): Influence of lead on repetitive behavior and dopamine metabolism in a mouse model of iron overload. Toxicol. Res., 30, 267-276.

Circu, M.L. and Aw, T.Y. (2010): Reactive oxygen species, cellular redox systems, and apoptosis. Free Radic. Biol. Med., 48, 749762.

Filipe, P., Silva, J.N., Silva, R., Cirne de Castro, J.L., Marques Gomes, M., Alves, L.C., Santus, R. and Pinheiro, T. (2009): Stratum corneum is an effective barrier to $\mathrm{TiO} 2$ and $\mathrm{ZnO}$ nanoparticle percutaneous absorption. Skin Pharmacol. Physiol., 22, 266-275.

Genova, M.L., Pich, M.M., Bernacchia, A., Bianchi, C., Biondi, A., Bovina, C., Falasca, A.I., Formiggini, G., Castelli, G.P. and Lenaz, G. (2004): The mitochondrial production of reactive oxygen species in relation to aging and pathology. Ann. N Y Acad. Sci., 1011, 86-100.

Heng, B.C., Zhao, X., Xiong, S., Ng, K.W., Boey, F.Y. and Loo, J.S. (2010): Toxicity of zinc oxide ( $\mathrm{ZnO}$ ) nanoparticles on human bronchial epithelial cells (BEAS-2B) is accentuated by oxidative stress. Food Chem. Toxicol., 48, 1762-1766.

Kang, H., Mintri, S., Menon, A.V., Lee, H.Y., Choi, H.S. and Kim, J. (2015): Pharmacokinetics, pharmacodynamics and toxicology of theranostic nanoparticles. Nanoscale, 7, 18848-18862.

Leung, Y.H., Chan, C.M., Ng, A.M., Chan, H.T., Chiang, M.W., Djurišić, A.B., Ng, Y.H., Jim, W.Y., Guo, M.Y., Leung, F.C., Chan, W.K. and Au, D.T. (2012): Antibacterial activity of $\mathrm{ZnO}$ nanoparticles with a modified surface under ambient illumination. Nanotechnology, 23, 475703.

Liu, S., Xu, L., Zhang, T., Ren, G. and Yang, Z. (2010): Oxidative stress and apoptosis induced by nanosized titanium dioxide in PC12 cells. Toxicology, 267, 172-177.

Long, T.C., Tajuba, J., Sama, P., Saleh, N., Swartz, C., Parker, J., Hester, S., Lowry, G.V. and Veronesi, B. (2007): Nanosize titanium dioxide stimulates reactive oxygen species in brain microglia and damages neurons in vitro. Environ. Health Perspect., 115, 1631-1637.

Menon, A.V., Chang, J. and Kim, J. (2016): Mechanisms of divalent metal toxicity in affective disorders. Toxicology, 339, 58-72.

Monteiro-Riviere, N.A., Wiench, K., Landsiedel, R., Schulte, S., Inman, A.O. and Riviere, J.E. (2011): Safety evaluation of sunscreen formulations containing titanium dioxide and zinc oxide nanoparticles in UVB sunburned skin: an in vitro and in vivo study. Toxicol. Sci., 123, 264-280.

Nativo, P., Prior, I.A. and Brust, M. (2008): Uptake and intracellular fate of surface-modified gold nanoparticles. ACS Nano, 2, 1639-1644.

Nazarenko, Y., Zhen, H., Han, T., Lioy, P.J. and Mainelis, G. (2012): Nanomaterial inhalation exposure from nanotechnology-based 


\section{J. Chang et al.}

cosmetic powders: a quantitative assessment. J. Nanopart. Res., 14.

Newman, M.D., Stotland, M. and Ellis, J.I. (2009): The safety of nanosized particles in titanium dioxide- and zinc oxide-based sunscreens. J. Am. Acad. Dermatol., 61, 685-692.

Park, E.J., Yi, J., Chung, K.H., Ryu, D.Y., Choi, J. and Park, K. (2008): Oxidative stress and apoptosis induced by titanium dioxide nanoparticles in cultured BEAS-2B cells. Toxicol. Lett., 180, 222-229.

Sadrieh, N., Wokovich, A.M., Gopee, N.V., Zheng, J., Haines, D., Parmiter, D., Siitonen, P.H., Cozart, C.R., Patri, A.K., McNeil, S.E., Howard, P.C., Doub, W.H. and Buhse, L.F. (2010): Lack of significant dermal penetration of titanium dioxide from sunscreen formulations containing nano- and submicron-size $\mathrm{TiO} 2$ particles. Toxicol. Sci., 115, 156-166.

Salatin, S., Maleki Dizaj, S. and Yari Khosroushahi, A. (2015): Effect of the surface modification, size, and shape on cellular uptake of nanoparticles. Cell Biol. Int., 39, 881-890.

Schilling, K., Bradford, B., Castelli, D., Dufour, E., Nash, J.F., Pape, W., Schulte, S., Tooley, I., van den Bosch, J. and Schellauf, F. (2010): Human safety review of "nano" titanium dioxide and zinc oxide. Photochem. Photobiol. Sci., 9, 495-509.

Schöneich, C. (1999): Reactive oxygen species and biological aging: a mechanistic approach. Exp. Gerontol., 34, 19-34.

Seifried, H.E., Anderson, D.E., Fisher, E.I. and Milner, J.A. (2007): A review of the interaction among dietary antioxiants and reactive oxygen species. J. Nutr. Biochem., 18, 567-579.

Serpone, N., Salinaro, A. and Emeline, A. (2001): Deleterious Effects of Sunscreen Titanium Dioxide Nanoparticles on DNA. Efforts to Limit DNA Damage by Particle Surface Modification. Proc. SPIE, 4258, 86-98.

Sharma, V., Shukla, R.K., Saxena, N., Parmar, D., Das, M. and Dhawan, A. (2009): DNA damaging potential of zinc oxide nanoparticles in human epidermal cells. Toxicol. Lett., 185, 211218.
Shukla, R.K., Kumar, A., Gurbani, D., Pandey, A.K., Singh, S. and Dhawan, A. (2013): TiO(2) nanoparticles induce oxidative DNA damage and apoptosis in human liver cells. Nanotoxicology, 7, 48-60.

Shukla, R.K., Sharma, V., Pandey, A.K., Singh, S., Sultana, S. and Dhawan, A. (2011): ROS-mediated genotoxicity induced by titanium dioxide nanoparticles in human epidermal cells. Toxicol. In Vitro, 25, 231-241.

Singh, P. and Nanda, A. (2014): Enhanced sun protection of nanosized metal oxide particles over conventional metal oxide particles: an in vitro comparative study. Int. J. Cosmet. Sci., 36, 273283.

van der Molen, R.G., Hurks, H.M., Out-Luiting, C., Spies, F., van't Noordende, J.M., Koerten, H.K. and Mommaas, A.M. (1998): Efficacy of micronized titanium dioxide-containing compounds in protection against UVB-induced immunosuppression in humans in vivo. J. Photochem. Photobiol. B, 44, 143-150.

Weir, A., Westerhoff, P., Fabricius, L., Hristovski, K. and von Goetz, N. (2012): Titanium dioxide nanoparticles in food and personal care products. Environ. Sci. Technol., 46, 2242-2250.

Xie, G., Lu, W. and Lu, D. (2015): Penetration of titanium dioxide nanoparticles through slightly damaged skin in vitro and in vivo. J. Appl. Biomater. Funct. Mater., 13, e356-e361.

Xiong, S., George, S., Yu, H., Damoiseaux, R., France, B., Ng, K.W. and Loo, J.S. (2013): Size influences the cytotoxicity of poly (lactic-co-glycolic acid) (PLGA) and titanium dioxide (TiO(2)) nanoparticles. Arch. Toxicol., 87, 1075-1086.

Ye, Q., Kim, J. (2015a): Effect of olfactory manganese exposure on anxiety-related behavior in a mouse model of iron overload hemochromatosis. Environ. Toxicol. Pharmacol., 30, 333-341.

Ye, Q., Kim, J. (2015b): Loss of hfe function reverses impaired recognition memory caused by olfactory manganese exposure in mice. Toxicol. Res., 31, 17-23.

Zielińska, A. and Nowak, I. (2014): Fatty acids in vegetable oils and their importance in cosmetic industry. CHEMIK, 68, 103-110. 